\title{
Okuma Eğitimi Üzerine Bir Kaynakça Denemesi
}

\author{
Mesut Bulut ${ }^{1}$, Salih Orhan ${ }^{2}$, Abdulkadir Kırbaş ${ }^{3}$ \\ Özet
}

İnsanoğlu için öğrenme yollarından en önemlilerinden biri de okumadır. Çünkü öğrenme faaliyetlerinde en çok okuma ile ilgisi bulunan görme ve işitime duyularından faydalanırız. "Okuma, beş duyu organının çeşitli hareketlerinden ve zihnin anlamı kavrama çabasından meydana gelen karmaşı bir faaliyettir. Genellikle, öğrendiklerimizin \% 1'ini tatma, \% 1,5'ini dokunma, \% 3,5'ini koklama, \%11'ini işitme, \% 83'ünü görme duyusu yoluyla elde etmekteyiz. Bu sonuçlara göre, göze ve kulağa hitap eden okumanın öğrenmede \%94 gibi önemli bir paya sahip olduğu ortaya çıkmaktadır." (Aytaş,2005). Yaşamımızda bu derece önem arz eden bir becerinin bireye nasıl kazandırılacağı ve bu bağlamda hangi çalışmaların yapılması gerektiği hususunda birçok araştırma yapılmış ve yapılmaya devam etmektedir. Zira okuma eğitimi alışkanlıktan ziyade eğitim yoluyla geliştirilebilecek bir beceridir.

$\mathrm{Bu}$ çalışmanın temel amacı, insan hayatında önemli bir yere sahip olan okuma eğitimi alanında yapılan makale, yüksek lisans tezi, doktora tezi, seminer ve bildiri gibi çalışmalardan ulaşabildiklerimizi bir araya getirerek bu alanda çalışacak olan araştırmacılara yardımcı olmaktır.

Anahtar kelimeler: Okuma, okuma eğitimi, okuma becerisi

\section{An Attempt of a Bibliography on Reading Education}

\begin{abstract}
For human beings, one of the most important ways of learning is to read, because during the process of learning, most activities utilize the senses of sight and hearing. "Reading is a complex activity that stem from the various movements of the five senses and the attempt of mind to comprehend the meaning. Usually, we obtain $1 \%$ of what we have learned through tasting, $1.5 \%$ through touching, $3.5 \%$, through smelling, $11 \%$ through hearing, $83 \%$ through the sense of sight. According to these

\footnotetext{
${ }^{1}$ Atatürk Üniversitesi Türk Dili ve Edebiyatı Eğitimi Doktora Öğrencisi e-mail: mesutbulut_77@yahoo.com

${ }^{2}$ Dr. Ilıca Yavuz Selim Anadolu Öğretmen Lisesi Türk Dili ve Edebiyatı Öğretmeni e-mail: salihorhan2009@hotmail.com

${ }^{3}$ Yrd. Doç. Dr. Gümüşhane Üniversitesi Türk Dili ve Edebiyatı Bölümü Öğretim Üyesi e-mail: kadir_smk@hotmial.com
} 
Bulut, M.; Orhan, S.; Kırbaş, A./ Sosyal Bilimler Araştırmaları Dergisi. I, (2012): 19-36

results, reading, being appealing to both the eye and the ear, appears to have a significant share of $94 \%$ in learning. "(Aytaş, 2005). Plenty of researches have been done and are still being carried out on how to make the individuals acquire a skill holding that much importance in our lives and what kind of studies are required in this context. Forasmuch as reading is a skill which can be developed through education rather than a habit.

The main purpose of this study, is to bring together such works as articles, master's thesis, doctoral thesis, seminars, and papers in the field of reading education which has an important place in human life and to help the researchers who will work in this field.

Key words: Reading, reading education, reading skills

\section{GíRiș}

İnsanoğlunun algıladığı şeyleri anlamlandırabilmesi, kendini ve çevresini tanıyabilmesi için okuma ve dolayısıyla da okuma eğitiminin büyük bir önemi bulunmaktadır. Eleştirel düşünme, problemlerin farkına varma ve bunlara çözüm yolları bulmada kısacası zihinsel her türlü faaliyetin geliştirilebilmesinde okumanın etkisi bulunmaktadır. İnsan hayatında ciddi bir öneme sahip olan okumaya yönelik birçok tanımlama yapılarak okumanın değişik yönleri dikkatlere sunulmuştur. Okumayı, Özbay (2007:4) "Göz yoluyla algılanan işaret ve sembollerin beyin tarafından değerlendirilmesi ve anlamlandırılması süreci" olarak tanımlarken okumanın okurla yazar arasındaki etkileşimini ön plana çıaran Akyol (2006: 29) "yazar ve okur arasındaki aktif ve etkili bir iletişimi gerekli kılan dinamik bir anlam kurma süreci” şeklinde tanımlamaktadır. Tanımlardan da anlaşılacağı üzere okuma zihinsel ve fiziksel bir süreç olarak insanı ve insanı kuşatan her şeyi algılama ve anlamlandırma aynı zamanda başkalarıyla iletişim kurma yolu olarak karşımıza çıkmaktadır.

Bir anlama becerisi olarak nitelendirdiğimiz okuma becerisinin geliştirilmesi ve bunun bir alışkanlık olarak kazandırılması için iyi bir okuma eğitimi verilmesi gerekmektedir. Hangi seviyede hangi metotların kullanılması gerektiğinden hangi seviyede hangi metinlerin okunmasına kadar birçok husus dikkate alınarak bir okuma eğitimi gerçekleştirilmelidir.

Okuma eğitiminde öncelikle bir amacın olması ve bu amaca göre okuma faaliyetinin yapılması gerekmektedir. Okumanın amacı Türkçe eğitim programında şu şekilde açıklanmaktadır: 
1. Öğrencilerin okuduklarını doğu ve çabuk anlama, tabii ve anlamlı okuma alışkanlıklarını geliştirerek sesli ve sessiz okumayı iyileştirmek,

2. Türlü konularda okuma ilgisini geliştirmek yoluyla öğrencinin kelime hazinesini zenginleştirmek ve okuma zevkini yükseltmek,

3. Türlü konularda okuma ilgisini geliştirmek yoluyla öğrencileri iyi bir karakter ve ülküye sahip etmek,

4. Öğrencilere güzel eserlerin güzelliğini duyurmak yoluyla onları estetik değerler üzerinde düşündürmek,

5. Öğrencilerde ilk gençlik devresinin duygululuğuna yararlı bir akım vermek ve bu duyguları değerli ve yararlı isteklere yöneltmek,

6. Öğrencilere türlü konularda bilgi kazandırmak, türlü bilim ve inceleme çalışmalarının gerektirdiği okumalarla edinilen yetenekleri geliştirmek,

7. Öğrencileri iyi eserlere istekli ve onlardan hoşlanır duruma getirmek, onlara boş zamanlarını okumakla geçirme alışkanlığını kazandırmak,

8. Çocuklarda kitap sevgisini ve kitap sahibi olma isteklerini yaratmak ve geliştirmek,

9. Türk dilini sevdirmek ve Türk Dil Devriminin amaçlarını gerçekleştirmek (M.E.B. 1995).

Ana dili eğitiminin en temel amaçlarından biri de öğrencilere okuma alışkanlığı ve zevki kazandırmaktır. Bunun en etkili olarak nasıl yapılacağı ve hangi yöntemlerin uygulanacağı bu alandaki uzmanların üzerinde önemle durdukları konuların başında gelmektedir. Yukarıda sayılan bütün bu amaçların gerçekleştirilebilmesi ancak iyi ve doğru bir okuma eğitimi ile mümkün olabilecektir. İşte bu alanda birçok çalışma yapılmıştır. Biz de bu alanda yapılacak çalışmalara yol göstermesi, kaynak olması amacıyla ulaşabildiğimiz kaynakların künyelerini bir liste hâlinde sunmayı yararlı gördük:

Acarlar, F, Ege, P. ve Turan, F. (2002). Türk çocuklarındı! Üst Dil Becerilerinin Gelişimi ve Okuma ile İlişkisi. Türk Psikoloji Dergisi. 17.63-7.1.

Adalı, O. (2003). Anlamak ve Anlatmak. Pan Yayınc1lı: Ankara.

Akçam, H.K. (2006). Görsel Okumanin Ilköğretim 5. Sınıf Bilgi Verici Metinlerde Anlam Kurmaya Etkisi. (Yayımlanmamış 
Yüksek Lisans Tezi). Ankara: Gazi Üniversitesi Eğitim Bilimleri Enstitüsü

Aksin, G. (1988). Okuma Uğraşı. İstanbul: İnkılâp Kitabevi.

Akyılmaz, L. Kocaoluk, M. Ş. (1992). İlk Okuma Yazma Öğretimi. İstanbul: Kocaoluk Yayınları.

Akyol, H. (1997). Okuma ve Prensipleri. Çağdaş Eğitim. (233) ss. 26-28.

.( 2005). Türkçe Illk Okuma Yazma Öğretimi. Ankara: Pagem A Yayıncilik.

. (2003). Türkçe Illk Okuma Yazma Öğretimi. Ankara: Gündüz Yayıncilik.

Altunay, U., Çakıcı, D. (2006). Etkili Okuma ve Okuduğunu Anlama. Çağdaş Eğitim. (330), ss. 40-46.

Anılan, H. (1998). 5. Sinıf Öğrencilerinin Türkçe Dersinde Okuduğunu Anlama Becerisiyle Ilgili Hedef Davranışlarının Gerçekleşme Düzeyleri. (Yayımlanmamış Yüksek Lisans Tezi). Denizli. Pamukkale Üniversitesi Sosyal Bilimler Enstitüsü.

Aktan ,E. (1996). Çocuğun Dil Gelişiminde Fonolojik Duyarlılı̆̆ın (Sesbilgisel Duyarlık) Karşılaştırmalı Olarak Incelenmesi. (Yayımlanmamış Yüksek Lisans Tezi). İstanbul: Marmara Üniversitesi Sosyal Bilimler Enstitüsü.

Alperen, N. (1989). Türkçe (Güzel Konuşma, Okuma ve Yazma) Öğretim Rehberi. İstanbul: MEB Yayınları.

(1994). Okuma Yazma Öğretimi Metodları ve Çözümleme Metodunun Türkçe Öğretimine Uygulanmast.

(Yayımlanmamış Yüksek Lisans Tezi). Ankara: Gazi Üniversitesi Sosyal Bilimler Enstitüsü.

Arıcı, A.F. ( 2008). Okumayı Niye Sevmiyoruz? Üniversite Öğrencileri ile Mülakatlar.

Mustafa Kemal Üniversitesi Sosyal Bilimler Enstitüsü Dergisi. C. 5. . (2008). Okuma Eğitimi. Ankara: Pegem Akademi. . (2008). "A National Reading Compaigne in Turkey: 100 Basic Literary Works", World Applied Science Journal, S. 3(2), s. 162-167 
Bulut, M.; Orhan, S.; Kırbaş, A./ Sosyal Bilimler Araştırmaları Dergisi. I, (2012): 19-36

Arıkök, İ. ( 2001). Beş-altı Yaş Çocuklarda Görsel Algı Eğitiminin Okuma Olgunluğuna Olan Etkisinin Incelenmesi. (Yayımlanmamış Yüksek Lisans Tezi). Ankara: Gazi Üniversitesi Sosyal Bilimler Enstitüsü Çocuk Gelişimi ve Eğitimi Anabilim Dalı.

Arığlu, S.(2001). The Teaching of Raeding Through Short Stories in Advanced Classes. (Yayımlanmamış Yüksek Lisans Tezi). Ankara: Hacettepe Üniversitesi Sosyal Bilimler Enstitüsü.

Arslan, D.( 2005). İlkokuma Öğretiminde Karşılaşılan Güçlükler ve Okumayı Geliştirici Duyuşsal Yaklaşımlar. (Yayımlanmamış Doktora Lisans Tezi). Bursa: Uludağ Üniversitesi Sosyal Bilimler Enstitüsü İlköğretim Anabilim Dalı.

Ateş, S. (2006). Illköğretim Dördüncü Sinıf Metinlerindeki Görsellerin Okuduğunu Anlama ve Özetleme Etkisi. (Yayımlanmamış Yüksek Lisans Tezi). Ankara: Gazi Üniversitesi Eğitim Bilimleri Enstitüsü.

Aygüneş, M.(2007). Yabancı Dil Olarak Türkçenin Öğretiminde Okuma Becerisini Geliştirme Yolları. (Yayımlanmamış Yüksek Lisans Tezi). İzmir: Dokuz Eylül Üniversitesi Eğitim Bilimleri Enstitüsü Yabancı Dil Olarak Türkçe Öğretimi Anabilim Dal1.

Aytaş, G.(2003). Okuma Gelişiminde Çocuk Edebiyatının Rolü. Türklük Bilimi Araştırmaları, (13). .(2005). Okuma Eğitimi. Türk Ĕgitim Bilimleri Dergisi. ( 4), 461-469.

Bamberger, R. (1990). Okuma Alışskanlı̆̆ını Geliştirme. ( Çev: Bengü ÇAPAR). Ankara: Kültür Bakanlığı Yay.

Bakırc1, H.H.( 2004). The Effectiveness Evaluation of Schema Induced Prereading Activities in Teaching Reading in ELT Classes. (Yayımlanmamış Yüksek Lisans Tezi). Konya: Selçuk Üniversitesi Sosyal Bilimler Enstitüsü.

Balun, H.(2008). Ilköğretim Birinci Kademede Uygulanan Görsel Okuma ve Görsel Sunu ögrrenme Alaninin Türkçe Öğretiminde Kazanımlara Ulaşmadaki Etkililiği (Bingöl-Elazı̆̆Diyarbakır Örneği). (Yayımlanmamış Yüksek Lisans Tezi). Elazığ: Fırat Üniversitesi Sosyal Bilimler Enstitüsü Eğitim Bilimleri Bölümü Eğitim Bilimleri Anabilim Dalı. 
Baş, Ö. (2004). Bütünsel Beyin Yaklaşımıyla ve Çoklu Zeka Kuramıyla Öğretimin Birinci Sinıf Öğrencilerinin Okuma ve Yazma Erişişine Etkisi. (Yayımlanmamış Yüksek Lisans Tezi). Ankara: Gazi Üniversitesi Eğitim Bilimleri Enstitüsü.

Baş, Ö. (2004). Bütünsel Beyin Yaklaşımıyla ve Çoklu Zeka Kuramıyla Ögrretimin Birinci Sinıf Öğrencilerinin Okuma ve Yazma Erişisine Etkisi. (Yayımlanmamış Yüksek Lisans Tezi). Ankara: Gazi Üniversitesi Gazi Üniversitesi Eğitim Bilimleri Enstitüsü Sınıf Öğretmenliği Anabilim Dalı.

Bekar, Ü. (2005). İlköğretim Birinci Sinıf Öğrencilerinin Okuıma Alışkanlığını Kazanmalarında Ailenin Rolü. (Yayımlanmamış Yüksek Lisans Tezi). Ankara: Gazi Üniversitesi Sosyal Bilimler Enstitüsü.

Baymur, F. (1954). Türkçe Öğretimi( İkinci Kitap) İlk Okuma-Okuma- Dil Bilgisi. İstanbul: İnk1lap Kitabevi.

Bayrav, S. ve Yerguz, İ. (2002). Okuma- Anlama- Yorumlama. İstanbul: Mult1lingual Yayınları.

Bedir, H. (1997). Okuma Anlamada Geçmiş Bilgilerin İşlevi. 4. Dil Bilim Kongresi Kitapçı̆̆ . Eskişehir: Anadolu Üniversitesi.

Bedir, H. (1995). Okuma Anlamada Kültürel Ögelerin Önemi. Ingilizce Ögrretiminde Neredeyiz, Malatya: İnönü Üniversitesi.

Bektaş, A.(2007). Ses Temelli Cümle Yöntemiyle Gerçekleştirilen Illk Okuma Yazma Öğretiminin Değerlendirilmesi. (Yayımlanmamış Yüksek Lisans Tezi). Adana: Çukurova Üniversitesi Sosyal Bilimler Enstitüsü Sınıf Öğretmenliği Anabilim Dali.

Beyazıt, N.(2007). İlk Okuma Yazma Öğretiminin Kazandırılmasında Çözümleme Yöntemi ve Ses Temelli Cümle Yönteminin Farklı Bakış Açılarıyla Değerlendirilmesi. (Yayımlanmamış Yüksek Lisans Tezi). Hatay: Mustafa Kemal Üniversitesi Sosyal Bilimler Enstitüsü İlköğretim Anabilim Dali.

Bildirici, K, Oruç, M. ve Ekizler, M. (2000). İlk Okuma Yazma Öğretiminde Çözümleme Metodu. İstanbul: Serhat Yayınları.

Binbaşığlu, C. (2004). Illkokuma ve Yazma Öğretimi. Ankara: Nobel Yayın Dağıtım: 
Bulut, M.; Orhan, S.; Kırbaş, A./ Sosyal Bilimler Araştırmaları Dergisi. I, (2012): 19-36

( 1993). Okuma'nın Mekanizması ve Okuma Aracının Bazı Nitelikleri. Çağdaş Ë̆itim. (193), 15-20.

Bircan, İ. ve Tekin, M. (1989). Türkiye'de Okuma Alışkanlığının Azalması Sorunu ve Çözüm Yolları. Ankara Üniversitesi Eğitim Bilimleri Fakültesi Dergisi. 22 (1), 393-410.

Bölükoğlu, A.(1999). Yabancı Dil Ağırlıklı Öğretim Uygulayan Gönen Ömer Seyfettin Süper Lisesi ve Gönen Anadolu Otelcilik ve Turizm Meslek Lisesi Hazırlık Sinıflarında Okutulan Türkçe Derslerinde Okuma Eğitimi. (Yayımlanmamış Yüksek Lisans Tezi). Çanakkale: Onsekiz Mart Üniversitesi Sosyal Bilimler Enstitüsü.

Brooks, T.D. ( 1936). Okumanın Tatbik Edilmiş Psikolojisi. (Çev: Rahmi A. Kolçak). İstanbul: Sirkeci Mürebbiye Basımevi.

Bülbül, S.A ve Diğerleri. (1999). Yetişkinlere Yönelik Okuma -Yazma Kurslarının Değerlendirilmesi Araştırmast: Ankara.

Bülbül, S. (1990). Türkiye'de Okuma Yazma Öğretimi Çalışmaları ve Alınan Sonuçlar, UNESCO İ̧in Hazırlanan Rapor. Çoğaltma : Ankara.

Calfee, R. ve P. Drum (1986). Research on Teaching Reading. Handbook of Research on Teaching (Ed. M. C. Wittrock) 3. Bask1. New York: Macmillan Company. p.804-848.

Camine, D.W.. Silberl. J. ve Kameenui E.J. (1997). Direct instruction reading. New Jersey: Prenlice-Hal. Inc.

Çolak, A. (2001). Zihin Özürlü Çocuklar İlköğretim Okulu ve Mesleki Eğitim Merkezindeki Özel Eğitim Öğretmenlerinin Zihin Özürlü Çocukların Okuma-Yazma Öğrenmeleri Hakkındaki Görüş ve Önerileri. (Yayınlanmamış Yüksek Lisans Tezi), Eskişehir: Anadolu Üniversitesi Sosyal Bilimler Enstitüsü.

Demirel, M. ( 1992). Temel Boyutlarıyla Okuduğunu Kavrama Süreci. Hacettepe Eğitim Fakültesi Dergisi. ss. 325- 334.

Corbalis, M.C. (2003). İşaretten Konuşmaya Dilin Kökeni ve Gelişsimi. (Çev: Aybek Giray). İstanbul: Kitap Yayınları.

Coşkun, E. ( 2000). Lise II. Sinıf Öğrencilerinin Sessiz Okuma Hızları ve Okuduğunu Anlama Düzeyleri Üzerine Bir Araştırma. 
(Yayımlanmamış Yüksek Lisans Tezi). Ankara: Gazi Üniversitesi Sosyal Bilimler Enstitüsü. (2003). Çeşitli Değişkenlere Göre Lise Öğrencilerinin Etkili Okuma Becerileri ve Bazı Öneriler. Türklük Bilimi Araştırmaları. ( 13), 101- 130.

Çam, B. (2006). İlköğretim Öğrencilerinin Görsel Okuma Düzeyleri İle Okuduğunu Anlama, Eleştirel Okuma ve Türkçe Dersi Akademik Başarıları Arasındaki İlişki. (Yayımlanmamış Yüksek Lisans Tezi). Eskişehir: Osmangazi Üniversitesi Sosyal Bilimler Enstitüsü.

Çelenk, S., Çalışkan, M. (2004). Bazı Sosyo-Ekonomik Faktörlerin Okuduğunu Anlama Başarısına Etkisinin İncelenmesi. Çă̆daş Ë̆itim. (310), 27.

Çiftçi, M. (2000). Sesli Okuma. Bilge. (24), Bahar, ss. 178-184.

Değirmenci, M.(2008). İlk Okuma Yazma Öğretiminde Ses Temelli Cümle Yönteminin Uygulanmasina Ilişkin Sinıf Öğretmenlerinin Görüşleri. (Yayımlanmamış Yüksek Lisans Tezi). İstanbul: Yeditepe Üniversitesi Sosyal Bilimler Enstitüsü Eğitim Yönetimi ve Denetimi Anabilim Dalı.

Demirel, M.(2006). İlk Okuma Yazma Öğretimindeki Değişiklikler Üzerine Bir Araştırma. (Yayımlanmamış Yüksek Lisans Tezi). Konya: Selçuk Üniversitesi Sosyal Bilimler Enstitüsü.

Demiriz, E.(1998). An Evaluation of the efficiency of the Pre-reading Tasks and Schema Activation Activities in Teaching Reading. (Yayımlanmamış Yüksek Lisans Tezi). Ankara: Orta Doğu Teknik Üniversitesi Sosyal Bilimler Enstitüsü.

Devramca, H. (1993). İlkokul 5. Sınıf Çocuklarında Okuma Alışkanlı̆̆ının Incelenmesi. Ankara: Hacettepe Üniversitesi Sağlık Bilimleri Enstitüsü Bilim Uzmanlığ Tezi.

Doğan, Y. (2002). Türkçe Öğretmenliği Birinci Sinıfta Okuyan Öğrencilerin Okuma ve Yazma Becerileri ile Genel Kültür Düzeyleri Üzerine Bir Araştırma. (Yayımlanmamış Yüksek Lisans Tezi). Ankara: Gazi Üniversitesi Eğitim Bilimleri Enstitüsü. 
Bulut, M.; Orhan, S.; Kırbaş, A./ Sosyal Bilimler Araştırmaları Dergisi. I, (2012): 19-36

Dökmen, Ü.(1994). Okuma Becerisi Illgisi ve Alışkanlı̆̆ Üzerine Psiko-sosyal Bir Araştırma. İstanbul: MEB Basımevi.

Dündar, R.(2006). Orta Düzeyde Zihinsel Engelli Çocuklara Okuma Ögrretiminde Ses Temelli Cümle ve Cümle Çözümleme Yönteminin Etkinliklerinin Karşılaş̧tırılması. (Yayımlanmamış Yüksek Lisans Tezi). Ankara: Hacettepe Üniversitesi Sağllk Bilimleri Enstitüsü Çocuk Gelişimi ve Eğitimi Anabilim Dalı.

Earge, P. (2003). 2001 Uluslar Arası Okuma Becerilerinde Gelişim Projesi. Ankara.

Erapek, S. (1998). Alt Özel Sınıf Öğrencilerinin İlkokul Sınıfları Düzeyinde Sesli Okuma Başarılarının Değerlendirilmesi. Anadolu Üniversitesi Ë̆itim Fakültesi Dergisi .(22)

Erginer, E. (2000). Anadil Ĕgitim Programları ve 2000'li Yıllar İçin Bir Model Önerisi. Eğitim Araştırmaları Dergisi, 1.

Ertürk, A. (2001). İlkokuma Yazma Öğretimi Hazırlı Devresinin Okumayazma Öğrenmedeki Yeri ve Önemi. (Yayımlanmamış Yüksek Lisans Tezi). İstanbul: Marmara Üniversitesi Eğitim Bilimler Enstitüsü İlköğretim Anabilim Dalı.

Esgan, A, Karadağ, Ö. (2000). Üniversite Öğrencilerinin Okuma Alışkanlı̆̆ı. Popüler Bilim. Eylül Sayısı. ss. 19-23.

Eyidoğan, F.(2005). Zihin Özürlü Öğrencilere Silikleştirilen Resimli Fiş Cümleleriyle Okuma-Yazma Öğretiminde Hata Düzeltmeli Eşzamanlı Ípucuyla Öğretimin Etkililiği. (Yayımlanmamış Yüksek Lisans Tezi). Eskişehir: Anadolu Üniversitesi Eğitim Bilimler Enstitüsü Özel Eğitim Anabilim Dalı.

Firenbiz, M.(1988). Türkçe Eğitim ve Öğretiminde Dört Önemli İlke, Türk Dilinin Öğretimi Toplantısı, Ankara: AÜ Eğitim Bilimleri Fakültesi Yayınları.

Göğüş, B. (1978). Orta Dereceli Okullarda Türkçe ve Yazma Eğitimi. Ankara. Gül Yayınevi.

Göktürk, A. (2001). Okuma Ŭgraşı. İstanbul: YKY.

Gönen, M, Öncü, E. ve Isitan, S. ( 2004). Illköğretim 5, 6 ve 7. Sinıf Öğrencilerinin Okuma Alışkanlıklarının Incelenmesi. Milli Eğitim Dergisi. (164). 
Graesser, A.; Golding, J. M; Long, D. L. (1991). Narrative Representation and Comprehension. Handbook of Reading Research V II. Newyork London: Longman. 171- 206.

Güçel, G.(1993).Cumhuriyet Döneminde Türkçe Öğretimi ve Okuma Yazma Allşkanlı̆̆ $\ddot{\text { Uzzerine }}$ Bir Değerlendirme. (Yayımlanmamış Yüksek Lisans Tezi). Ankara: Gazi Üniversitesi Sosyal Bilimler Enstitüsü.

Gül, G.(2006). Hafif Derecede Zihinsel Engelli Çocukların Okuma Becerilerine Ses Bilgisel Farkındalık Becerileri Eğitiminin Etkisinin Incelenmesi. (Yayımlanmamış Yüksek Lisans Tezi). Ankara: Hacettepe Üniversitesi Sağlik Bilimleri Enstitüsü Özel Eğitim Anabilim Dalı.

Güler, H. (2007). Non-native EFL Teavhers Beliefs About Teaching Reading. (Yayımlanmamış Yüksek Lisans Tezi). Eskişehir: Anadolu Üniversitesi Sosyal Bilimler Enstitüsü Yabancı Diller Eğitimi Anabilim Dalı.

Güleryüz. H. (2000). Programlanmış ilkokuma yazına öğretimi Ankara: Pegem Yayınc1lik.

Gülşin,F.(2005). Sinıf Öğretmenlerine Göre İlk Okuma Yazma Öğretiminde Kullanılan Fişlerin Iç̧eriği ve Fiş Seçiminde Dikkat Edecekleri Hususlar( Konya İi Çumra Örneği). (Yayımlanmamış Yüksek Lisans Tezi). Konya: Selçuk Üniversitesi Sosyal Bilimler Enstitüsü İlköğretim Anabilim Dal1.

Gündemir, Y. (2002). İlköğretim Sekizinci Sinıf Öğrencilerinin Okuduğunu Anlama Becerilerinin Gelişimlerinin Ölçülmesi. (Yayımlanmamış Yüksek Lisans Tezi). Ankara: Gazi Üniversitesi Eğitim Bilimleri Enstitüsü Türkçe Öğretmenliği Bilim Dalı.

Gürcan, H. İ. (1996). Okuma Alışkanlı̆̆ ile Kitap Yayımcılığının Kültürel Illetişim ve Teknolojiye Bă̆l Sorunları Karşısında Türkiye Koşullart Temelinde Bir Model Önerisi. (Yayımlanmamış Doktora Tezi). Eskişehir: Anadolu Üniversitesi Sosyal Bilimler Enstitüsü. 
Güneş, F. (1997). Okuma- Yazma Öğretimi ve Beyin Teknolojisi. Ankara: Ocak Yayınlar1.

Güneş, M. (1997). İlkokul Öğrencilerinin Okuma Düzeyleri ve Dikkat Özelliklerinin Bazı Değişkenler Açısından İncelenmesi. (Yayımlanmamış Yüksek Lisans Tezi). Ankara: Gazi Üniversitesi Sosyal Bilimler Enstitüsü.

Güneş, F. ve Diğerleri (2000). Herkes İçin Okuma Yazma Kitabı. Ankara.

Güneş, F. (1992). Yetişkinlere Okuma- Yazma Öğretimi. Ankara: Yaygın Eğitim Enstitüsü.

Güngör, A. (2005). Altıncı, Yedinci ve Sekizinci Sinıf Öğrencilerinin Okuduğunu Anlama Stratejilerini Kullanma Düzeyleri. Hacettepe Üniversitesi Eğitim Fakültesi Dergisi. (28), ss. 101-108.

Gülbay, Ö. (2000). Yetişskin Okur Yazarlığı. Ankara: MEB Yay.

Gülbey, Ö. ve Diğerleri. (2002). Kolaylaştırılmış Okuma- Yazma Eğitimi Uygulamalarının Değerlendirilmesi. Ankara.

Hall , K.M., Sabey, Brenda L.; Mcclellan M. (2005). Expository Text Comprehension: Helping Primary-Grade Teachers Use Expository Texts To Full Advantage. Reading Psychology (26), p.211- 231.

Harris, A. J. and Sipay, E. R. ( 1990). How To Increase Reading Ability. (Ninth Edition). New York: Longman.

Hersan, Z.M.(1998). The Integration of Reading and Writing Through Pair and Group Work. (Yayımlanmamış Yüksek Lisans Tezi). Ankara: Hacettepe Üniversitesi Sosyal Bilimler Enstitüsü.

İşeri, K. (1998). Okuma Ediniminin Eğitimsel İşlevi. Tömer Dil Dergisi, A ğustos, (70) ss.5-18.

Karakuş Tayşi, E.Ş (2007). İlköğretim 5. ve 8. Sinıf Öğrencilerinin Hikaye ve Deneme Türü Metinlerindeki Okuduğunu Anlama Becerilerinin Karşılaşıtırılması (Kütahya İli Örneği). (Yayımlanmamış Yüksek Lisans Tezi). Ankara: Gazi Üniversitesi Eğitim Bilimleri Enstitüsü.

Karatay, H. (2007). Illköğretim Türkçe Öğretmeni Adaylarının Okuduğunu Anlama Becerileri Üzerine Alan Araştırmast. 
(Yayımlanmamış Yüksek Lisans Tezi). Ankara: Gazi Üniversitesi Eğitim Bilimleri Enstitüsü.

Kaya, K. (2005). Birleştirilmiş Sinıflar ile Bağımsız Sınıflarda İlk Okuma

Yazma Öğretiminde Karşılaşılan Sorunların

Karşılaştırmalı İncelemesi (Kayseri Ili Örneği).

(Yayımlanmamış Yüksek Lisans Tezi). Kayseri:

Erciyes Üniversitesi Sosyal Bilimler Enstitüsü.

Kellner, D. (2002). Yeni Teknolojiler/Yeni Okur-Yazarlıklar: Yeni Binyllda

Eğitimin Yeniden Yapılandırılmast. Kuram ve Uygulamada Eğitim Bilimleri. Mayıs 2002, 2 (1), ss. 107-132.

Kılıç, M. (1996). İlk Okuma Yazma Öğretiminde Temel Problemler.

(Yayımlanmamış Doktora Lisans Tezi). Ankara: Gazi Üniversitesi Sosyal Bilimleri Enstitüsü.

Kıran (Eziler), A. ve Kıran, Z. (2003). Yazınsal Okuma Süreçleri. Ankara: Seçkin Yayıncılık.

Köksal, K.(2001). Okuma Yazmanın Öğretimi. Ankara: PagemA Yayıncılık. Kuzu Sarar, T. ( 2004). Etkileşimsel Modele Uygun Okuma Öğretiminin Türkçe Bilgilendirici Metinleri Anlama Düzeyine Etkisi. Ankara Üniversitesi Eğitim Bilimleri Fakültesi Dergisi. (1), 55-77.

.(1999). Yabancı Dil Öğretiminde Okuma-Anlama Becerisinin Kazandırılması. (Yayımlanmamış Doktora Lisans Tezi). Eskişehir: Anadolu Üniversitesi Sosyal Bilimler Enstitüsü Alman Dili Eğitimi Anabilim Dalı.

Küçük, S. (1998). Şiirleşmenin İlköğretim 6. Sinff Öğrencilerinin Okuma Anlama Becerisine Etkileri. (Yayımlanmamış Doktora Lisans Tezi). Ankara: Gazi Üniversitesi Sosyal Bilimler Enstitüsü.

Luma S.(2002). İlköğretim Okulu Yedinci Sinff Öğrencilerinin Okuma Beceri ve Alışkanlıklarını Gelişstirmeye Yönelik Uygulamalı Bir Araştırma. (Yayımlanmamış Yüksek Lisans Tezi). Ankara: Gazi Üniversitesi Eğitim Bilimleri Enstitüsü.

McNinch, G. W. ve Steelman, P. (1990). Perceived Reading Status of Teacher Education Students. Reading Improvement, Fall. 27 (3), 203-206. 
MEB.(1979). Illk Okuma Yazma Öğretimi Kılavuzu. Ankara: MEB Basımevi.

MEB, ÇYEGM. (2001). Yetişkinler Okuma Kitabı Alıştırma Kitabı. Ankara. .( 2002). Yetişkinler Okuma Kitabı Alıştırma Kitabı. Ankara:

MEB Basımevi.

.(2000). Yetişkinler Okuma Kitabı Öğretmen Kılavuzu. Ankara:

MEB Basımevi.

.(1999). Yetişkinler Okuma Kitabı. Ankara.

.(2002). Yetişkinler Okuma Kitabı. Ankara.

Maraş11, A. (2005). Okumayı Sevdirme Yolları. Bilge Yayıncılık: İstanbul.

Muhtar, S.(2006). Üstbilişsel Strateji Eğitiminin Okuma Becerisinde Öğrenci

Başarısına Olan Etkisi. (Yayımlanmamış Yüksek

Lisans Tezi). Ankara: Ankara Üniversitesi Sosyal Bilimler Enstitüsü.

Nohl ,M. / Sayılan, F. (2004). Türkiye'de Yetişkinler için Okuma Yazma Eğitimi. Temel Eğitime Destek Projesi Teknik Raporu (Milli Eğitim Bakanlığ1/Avrupa Komisyonu).

Ocak, G. (2004). İlköğretim Okulu 5. Sinlf Öğrencilerinin Okuma Anlama Düzeyine Videonun Etkisi. Illköğretim- Online, (2), 1925.

Oğuzkan, A.F. (1991). Okuma Öğretimi. Türk Dili ve Edebiyatı Öğretimi. Eskişehir: Anadolu Üniversitesi Açık Öğretim Fakültesi Yayın1, ss. 76-95.

. (1990). Okuma Sanatı: Neler Okumall- Nasıl Okumalı. İstanbul:

İnk1lap Yayınevi.

Oğuzkan, F.(1999). "İyi Bir Kitabın Çocuğun Ruhsal ve Düşünsel Gelişmesine

Katklsı Var mıdır?" IIlköğretim Güzel Konuşma ve Yazma. İstanbul: Ok-yay Yayınları:

Oelwein, P.L. (1995). Teaching reading to children with down syndrome. Bethesda, MD; Woodbine House, Inc.

Okay, O. (2004). Okumayan Toplum. Türk Dili. Sayı: 629, 411-424.

Olçum, Y.(1992). İlk Okuma Yazma Öğretiminde Karşılaşılan Güçlükler Konusunda Öğretmenlerin Görüşleri. (Yayımlanmamış Yüksek Lisans Tezi). Ankara: Hacettepe Üniversitesi Sosyal Bilimler Enstitüsü. 
Olsen, M. W. ve Gillis, M. (1983). Teaching Reading Study Skills and Course Content to Preservice Teachers. Reading World. December. 23 (2). 124-133.

Ong, W.J. (1995). Sözlü ve Yazılı Kültür. İstanbul: Metis Yayınları.

Onan, B.(2005). İlköğretim İkinci Kademe Türkçe Öğretiminde Dil Yapılarının Anlama Becerilerini (Okuma/Dinleme) Geliştirmedeki Rolü. (Yayımlanmamış Doktora Lisans Tezi). Ankara: Hacettepe Gazi Üniversitesi Sosyal Bilimler Enstitüsü Türkçe Eğitimi Anabilim Dalı.

Ortac, D. (2007). Kitap Okuru Bir Toplum muyuz? (http://www.uniaktivite.net) Öney, B. Peter, M. And Katz, R.B. (1994). Printed word naming as a functional of age and orthographic transparency. Journal of the Scientific Study of Reading, 1-23.

Öz, F. (1995). Türkiye Cumhuriyetinde Okuma- Yazma Seferberlikleri ve Yönetimi. : Ankara.

Özak, H.(2008). Zihinsel Yetersizliği Olan Öğrencilere Okuma Becerilerinin Öğretiminde Bilgisayar Aracılı̆̆ıla Sunulan Eşzamanlı Ípucuyla Öğretimin Etkililiği. (Yayımlanmamış Yüksek Lisans Tezi). Bolu: Abant İzzet Baysal Üniversitesi Sosyal Bilimler Enstitüsü Özel Eğitim Anabilim Dalı.

Özçelebi, O.S. ve Cebecioğlu, N.S. ( 1990). Okuma Alışkanlı̆̆ ve Türkiye, Türkiye'de Okuma Allşkanlığı Olmaması Sorunu, Nedenleri ve Çözüm Yolları. İstanbul: Milliyet Yayınları.

Özçiçek, N.(1983). Ortaokullarda Türkçe Öğretiminin Etkililiği. (Yayımlanmamış Yüksek Lisans Tezi). Ankara: AÜ Sosyal Bilimler Enstitüsü.

Özdemir, E.(1990). Okuma Sanatı. İstanbul: Remzi Kitabevi: .(1983). Okuma Sanatı. İstanbul: Varlık Yayınları. .(2002). Eleştirel Okuma. Ankara: Bilgi Yayınevi.

Özen, F. (1998). Türkiye'de Okuma Alışkanlığ ve Öğretmenin Sorumluluğu. Eğitim Sen Demokratik Eğitim Kurultay1, 2-6 Şubat 1998. 571-590. Ankara: Volkan Matbaas1

Özen, F. (2001). Türkiye'de Okluma Alışkanlı̆̆ı. Ankara: Kültür Bakanlığı Yayınları. 
Özenç, E.G.(2007). İlk Okuma ve Yazma Öğretiminde Oyunla Öğretim Yöntemine İlişkin Öğretmen Görüşlerinin İncelenmesi. (Yayımlanmamış Yüksek Lisans Tezi). İstanbul: Marmara Üniversitesi Eğitim Bilimleri Enstitüsü İlköğretim Anabilim Dalı.

Özsoy, Y.(1987). Okul Sonrası Yaşamda Okuma. Anadolu Üniversitesi Eğitim Fakültesi Dergisi. 2: (1), ss.93-99. .(1990). Kültürlerarası Bildirişimde Etkin Bir Süreç: Yabancı Dilde Okuma Anlama. Alman Dili ve Edebiyatı Dergisi VII. İstanbul: İstanbul Üniversitesi Edebiyat Fakültesi Yayın1, ss. 69-90.

Özsoy, U. (2006). Ses Temelli Cümle Yöntemiyle Okuma Yazma Öğretiminde Karşılaşılan Güçlükler (Eskişehir İli Örneği). (Yayımlanmamış Yüksek Lisans Tezi). Eskişehir: Osmangazi Üniversitesi Sosyal Bilimler Enstitüsü İlköğretim Anabilim Dalı.

Razon, N. (1988). Okuma Güçlükleri, İstanbul Üniversitesi Yayımlanmamış Ders Notu.

Richek, M.A.. Caldwell. J.A., Jennings, C.H. ve Lerner. J.V. (2002). Heading problems assessment and teaching Strategies. (4. Bask1) Boston: Allyn and Bacon.

Ruşen, M. (1995). Hızlı Okuyarak Anlama ve Seçmeli Okuma Yöntemleri. İstanbul: Alfa Yayınları.

Saygıl1, S. (2002). Çocuklarda Okuma Alışkanlı̆̆ını Nasıl Kazandırmalı? Sağlık Yolu Dergisi. S.1.

Samancı, S.( 2007). Ses Temelli Cümle Yöntemiyle Okuma Yazma Öğretiminde Illköğretim Birinci Sinı Öğretmenlerinin Karşılaştıkları Problemler. (Yayımlanmamış Yüksek Lisans Tezi). Afyon: Kocatepe Üniversitesi Sosyal Bilimler Enstitüsü İlköğretim Anabilim Dalı.

Saracaloğlu, A. S., Bozkurt, N. ve Serin, O. (2003). Üniversite Öğrencilerinin Okuma Ilgileri ve Okuma Allşkanlıklarını Etkileyen Faktörler. Eğitim Araştırmaları. Yaz 2003, Y11: 4, Sayı: 12. ss. 148-157.

Saracaloğlu, A. S., Bozkurt, N. ve Serin, O. (2003). Üniversite Öğrencilerinin Okuma Illgileri ve Okuma Allşkanlıklarını Etkileyen 
Faktörler. Eğitim Araştırmaları. Yaz 2003, Y11: 4, Sayı: 12. ss. 148-157.

Sayılan, B. Ve Ş. (2001). Ankara'nın Gecekondu Bölgelerinde Yaşayan Okumaz Yazmaz ve İssiz Kadınların Tespiti Araştırması. Ankara: UNDP-KSSGM-KASAUM.

Sanc1, D. (2002). Illköğretim Altıncı Sinıf Öğrencilerinin Toplumsal, Ekonomik ve Kültürel Durumlarının Okuma Motivasyonlarına Etkisi. (Yayımlanmamış Yüksek Lisans Tezi). Erzurum: Atatürk Üniversitesi Sosyal Bilimler Enstitüsü.

Sertdemir, Y.(1995). Does the Testing Method Make a Difference in Measuring Reading Skills? A Case Study. (Yayımlanmamış Yüksek Lisans Tezi). Ankara: Orta Doğu Teknik Üniversitesi Sosyal Bilimler Enstitüsü.

Sever, S. (1993). Türkçe Öğretiminde Uygulanan Tam Öğrenme Kuramı İlkelerinin Öğrencilerin Okuduğunu Anlama ve Yazılı Anlatım Becerilerindeki Erişiye Etkisi. (Yayımlanmamış Doktora Tezi). Ankara: Ankara Üniversitesi Sosyal Bilimler Enstitüsü.

Sidekli, S. (2005). İlköğretim Beşinci Sinıf Öğrencilerinin Öğretici ve Öyküleyici Metinlere Göre Okuduğunu Anlama Becerilerinin Sinanması. (Yayımlanmamış Yüksek Lisans Tezi). Ankara: Gazi Üniversitesi Eğitim Bilimleri Enstitüsü.

Sumak, M.S.(1992). Identification of the Reading Comprehension Needs of the Freshman Students at the University of Gaziantep. (Yayımlanmamış Yüksek Lisans Tezi). Gaziantep: Gaziantep Üniversitesi Sosyal Bilimler Enstitüsü.

Şahin, A. (2005). Illk Okuma-Yazma Öğretiminde Kullanılan Çözümleme ve Bireşim Yöntemlerinin Uygulamall Olarak Karşılaştırılması. (Yayımlanmamış Doktora Tezi). Ankara: Gazi Üniversitesi Eğitim Bilimleri Enstitüsü İlköğretim Anabilim Dalı.

Şengül, M.; Yalçın, S. K. (2004). Okuma ve Anlama Becerilerinin Geliştirilmesine Yönelik Olarak Hazırlanan Bir Model Önerisi. Milli Ĕgitim Dergisi. (164). 
Şenol, M. (1999). Ísmail Hakkı Baltacıŏ̆lu'na Göre Okuma Eğitimi. AKÜ, Sosyal Bilimler Dergisi. (3). ss. 97-105.

.(1999). Okuma Yazma Öğretiminin Tasviri Bibliyografyast.

(Yayımlanmamış Yüksek Lisans Tezi). Afyon: Afyon

Kocatepe Üniversitesi Sosyal Bilimler Enstitüsü.

Tazebay, A.( 1997). Illkokul Öğrencilerinin Okuma Becerilerinin Okuduğunu Anlamaya Etkisi. Ankara: MEB Yayınları.

Temiz, N.(2004). Implications of Multiple Intelligences Theory on 1 st Graders Literacy Education. (Yayımlanmamış Yüksek Lisans Tezi). Ankara: Orta Doğu Teknik Üniversitesi Sosyal Bilimler Enstitüsü.

Temur, T. (2002). Illköğretim 5. Sinıf Türkçe Ders Kitaplarında Bulunan Metinler ile Öğrenci Kompozisyonlarının Okunabilirlik Düzeyleri Açısından Karşılaş̧tırılmast.

(Yayımlanmamış Yüksek Lisans Tezi). Ankara: Gazi Üniversitesi Eğitim Bilimleri Enstitüsü.

Tekin, H. (1980). Okullarımızdaki Türkçe Öğretimi. Ankara: Mars Matbaası. . (1980). Okuduğunu Anlama Gücü ile Yazıll Anlatım Becerisini Geliştirme Yönünden Okullarımızda Türkçe Öğretimi. Ankara: Mars Matbaası:

Tezcan, N. ( 1983). Yükseköğretimde Anadili Öğretimi. Türk Dili Dergisi. 379380. ss.73-76.

Tokta, M.C.(2008). Zihinsel Yetersizliği Olan Kaynaştırma Öğrencilerinde Ses

Temelli Yöntemin Okuma Yazma Öğretimine Etkililiğine İlişkin Öğretmen Görüşleri.

(Yayımlanmamış Yüksek Lisans Tezi). Bolu: Abant İzzet Baysal Üniversitesi Sosyal Bilimler Enstitüsü Özel Eğitim Anabilim Dalı.

Tuncel, B. (1992). Okuma-Anlama Başarısı, (Yayımlanmamış Doktora Tezi). İstanbul: İstanbul Üniversitesi Sosyal Bilimler Enstitüsü Uçar, K. Ö. D. (2001). Okuma Yazma Öğretiminde Kullanılan Yöntemlerin Etkinliğinin Araştırılması. (Yayımlanmamış Yüksek Lisans Tezi). Niğde: Niğde Üniversitesi Sosyal Bilimler Enstitüsü Eğitim Bilimleri Anabilim Dalı. 
Weaver, C. A, Kintsch ,W. (1991). Expository Text. Handbook of Reading Research V II. Newyork London: Longman. p. 230245.

Yaşar, Ş. (1993). Yabancı Dilde Okuma Becerilerinin Geliştirilmesinde Küçük Gruplarla Ö̆gretim Yönteminin Etkililiği. Eskişehir: Anadolu Üniversitesi Eğitim Fakültesi Yayını, S.34.

Yavuz, H. (1987). Okuma Alışkanlı̆̆ Üzerine. Çocuk Edebiyatı Yıllığı. İstanbul: Gökyüzü Yayınları, ss.266-267,

Yavuzer, H. (2003). Okuma Alışkanlığının Kazanılmasında Ailenin Rolü, Aileler ve Eğitimcilere Çocuk Kitapları Rehberi. İstanbul: Erkan Yayınları:

Yazar, U.(2001). Teaching Reading Effectively with Reading Strategies. (Yayımlanmamış Yüksek Lisans Tezi). Erzurum: Atatürk Üniversitesi Sosyal Bilimler Enstitüsü.

Yıldız, A. (2000). Üniversite Öğrencilerinin Okuma Alışkanlıklarını Belirleyen Etmenler. (Yayımlanmamış Yüksek Lisans Tezi). İstanbul: Marmara Üniversitesi Sosyal Bilimler Enstitüsü.

.(2006). Türkiye'de Yetişkin Okuryazarlığı: Yetişkin Okuma-yazma Eğitimine Eleştirel Bir Yaklaşım. (Yayımlanmamış Doktora Tezi). Ankara: Ankara Üniversitesi Eğitim Bilimleri Enstitüsü Eğitim Bilimleri Anabilim Dalı.

Y1lmaz, V.( 2004). Yabancı Dil Türkçe Öğretiminde Okuma Becerilerinin Geliştirilmesine Yönelik Görev Odaklı Bir Yordam Oluşturumu ve Gereç Hazırlamaya Yönelik Bir Çalışma. (Yayımlanmamış Yüksek Lisans Tezi). İstanbul: Yıldız Teknik Üniversitesi Sosyal Bilimler Enstitüsü Eğitim Bilimleri Anabilim Dalı.

Yurdaışı, A.(2007). Teachers' Views About and Approaches to Reading Instruction. (Yayımlanmamış Yüksek Lisans Tezi). Adana: Çukurova Üniversitesi Sosyal Bilimler Enstitüsü İngiliz Dili Eğitimi Anabilim Dalı. 